\title{
Alterations of the Giant Pyramidal Neurons (Betz Cells) in Brain Cortex of Rat Offspring Born from Gestational Diabetic Dams: A Morphometric Study
}

\author{
Alteraciones de las Neuronas Piramidales Gigantes de la Corteza Cerebral en Crías de Ratas \\ Nacidas de Hembras con Diabetes Gestacional: Un Estudio Morfométrico
}

\author{
Soraya Ghafari*; Elnaz Golalipour** \& Mohammad Jafar Golalipour***
}

GHAFARI, S.; GOLALIPOUR, E. \& GOLALIPOUR, M. J. Alterations of the giant pyramidal neurons (Betz cells) in brain cortex of rat offspring born from gestational diabetics dams: a morphometric study. Int. J. Morphol., 33(3):1120-1125, 2015.

SUMMARY: A few studies reported the adverse effects of gestational diabetes on hippocampus and spinal cord of rat offspring. Giant pyramidal neurons are giant pyramidal neurons located in fifth layers of the gray matter in the primary motor cortex. Therefore, this study was conducted to determine the effect of gestational diabetes on the giant pyramidal neurons and the thickness of internal pyramidal layer in the brain cortex of rat offspring. On day 1 of gestation, 10 Wistar rat dams were randomly allocated into two control and diabetic groups. Five animals in diabetic group received $40 \mathrm{mg} / \mathrm{kg} / \mathrm{BW}$ of Streptozotocin (intraperitoneally) and control animals received normal saline. We randomly selected six offspring of every subject in both groups at day 28,56 and 84 . Rat offspring were scarified and then coronal sections were taken from the right brain cortex and sections were stained with Cresyl violet. The density of giant pyramidal neurons in brain cortex and thickness of internal pyramidal layer of brain cortex were evaluated. In P28, P56, P84 the Betz cells density of brain cortex were significantly reduced from $107.6 \pm 6.2,131.6 \pm 4.6$ and $143.5 \pm 4.0$ in controls to $84.96 \pm 2.1,109.8 \pm 7.3$ and $121.05 \pm 5.6$ in cases ( $p<0.05$ ), respectively. The thickness of the internal pyramidal layer of brain cortex in P28, 56 and P84 was significantly higher in gestational diabetic group in comparison with the control group $(\mathrm{p}<0.05)$. This study showed that uncontrolled gestational diabetes reduces the giant pyramidal neurons density and internal pyramidal layer thickness in brain cortex of rat offspring.

KEY WORDS: Gestational diabetes; Neuron; Giant pyramidal neurons; Cerebral cortex; Rat offspring.

\section{INTRODUCTION}

Diabetes mellitus as a serious metabolic disorder characterized by hyperglycemia, altered metabolism of lipids, carbohydrates and proteins (Lebed et al., 2008) and is associated with cerebral alterations (Biessels et al., 2002; Gispen \& Biessels, 2000; McCall, 1992) including abnormal expression of hypothalamic neuropeptidase, hippocampal astrogliosis (Saravia et al., 2002) decreased hippocampal synaptic plasticity, neurotoxicity, changes in glutamate neurotransmission (Gardoni et al., 2002) and hippocampal neuron density are dysfunctions of the central nervous system (Golalipour et al., 2012).

Diabetes mellitus classified to type I or insulin dependent, type II or insulin independent and Gestational diabetes (Persaud, 2007). Gestational diabetes mellitus (GDM) defined as impaired glucose tolerance affects approximately $4 \%$ of all pregnant women who have never before had diabetes, but who do have high blood glucose levels during pregnancy (Persaud).

Several studies have reported the adverse effects of diabetic pregnancy on the developing brain including neurobehavioral deficits in both sensory-cognitive and psychomotor functions, such as altered auditory recognition memory processing at birth (Siddappa et al., 2004), reduced visual and memory performance at 8 and 12 months (DeBoer et al., 2005), poorer performance on tests of general development in infants and toddlers and inferior performance in elementary school children (Ornoy, 2005), motor delay may be a sign of mild, nonspecific brain damage and the abnormalities in memory processing (Nelson et al., 2000).

\footnotetext{
* Histology laboratory, Department of Anatomical Sciences, Golestan University of Medical Sciences, Gorgan, Iran.

*** Shahid Beheshti University of Medical Sciences, Tehran. Iran.

**** Professor, Gorgan Congenital Malformations Research Center, Golestan University of Medical Sciences, Gorgan, Iran.
} 
Although, several studies reported the adverse effects of type I and type II diabetes mellitus on hippocampus, hypothalamus, cerebellum and cerebrum (Ahmadpour \& Haghir, 2011; Beauquis et al., 2006; Jackson-Guilford et al., 2000; Khaksar et al., 2010; Li et al., 2002; Piotrowski et $a l ., 2001)$ and studies have shown the adverse effects of gestational diabetes on hippocampus, spinal cord and cerebellum (Golalipour et al., 2012, 2014; Najafdari et al., 2014; Razi et al., 2014), but there is no study about the effect of gestational diabetes on neuronal development of the giant pyramidal neurons and internal pyramidal layer thickness in brain cortex. Therefore, this experimental study was designed to assess the effect of gestational diabetes on the giant pyramidal neurons density and internal pyramidal layer thickness in brain cortex of rat offspring in the postnatal 28, 56 and 84 days of Wistar rats.

\section{MATERIAL AND METHOD}

This experimental study was performed at the Golestan University of medical sciences, Gorgan, Iran. Guidelines on the care and use of laboratory animals and approval of the ethic committee of Golestan University of medical sciences were obtained before study.

Experimental animals. Wistar rats, weighing $180-220$ g (12 weeks old) were used in this study. The animals were maintained in a climate-controlled room under a 12-hour alternating light/dark cycle, $20^{\circ} \mathrm{C}$ to $22^{\circ} \mathrm{C}$ temperature, and $50 \%$ to $55 \%$ relative humidity. Dry food pellets and water were provided ad libitum.

Drug . Streptozotocin (STZ) (Sigma, St. Louis, MO, USA) dissolved in sterile saline solution $(0.85 \%)$ to give $40 \mathrm{mg} /$ $\mathrm{kg}$ dose intraperitoneally (IP) injected to female rats.

Animal groups and treatment. After 2 weeks of acclimation to the diet and the environment, female Wistar rats were placed with a proven breeder male overnight for breeding. Vaginal smears were done the next morning to check for the presence of sperm. Once sperm was detected that day was assigned as gestational day $1(\mathrm{GD})$. On day 1 of gestation, pregnant females randomly divided into two control and diabetic groups (Fahrenkrog et al., 2004).

Five female rats in diabetic group receiving $40 \mathrm{mg} / \mathrm{kg} / \mathrm{body}$ weight of streptozotocin (STZ) and control groups (five rats) receiving an equivalent volume normal saline injection intraperitoneally. Blood was sampled from the tail at 1 week after STZ injection. The mothers with blood glucose level $120-250 \mathrm{mg} /$ $\mathrm{dl}$ known as gestational diabetic mothers (Schoenle et al., 2002).
The pregnancy of dams was terminated physiologically. In postnatal days of 28,56 and 84 , from each dam in control and cases six offspring randomly selected and were scarified. For light microscope preparations brain was fixed in $10 \%$ neutral-buffered formalin for histological procedure. The coronal sections (6 micrometer) serially collected from bregma $-3.12 \mathrm{~mm}$ to $4.68 \mathrm{~mm}$ of the primary motor cortex (Paxinos \& Watson, 1998). The sections were stained with cresyl violet.

Blood glucose measurements . Blood glucose level of mothers (before mating and after STZ injection) and offspring was obtained via tail vein and was estimated with a glucometer (ACCU-CHEK ${ }^{\circledR}$ Active Glucometer, Roche Diagnostics, Mannheim, Germany).

Morphometric techniques. For histomorphometric study, the sections were observed under the light microscope. In each offspring, ten similar sections of anterior to posterior of the primary motor cortex were selected and images by Olympus BX 51 microscope and DP12 digital camera

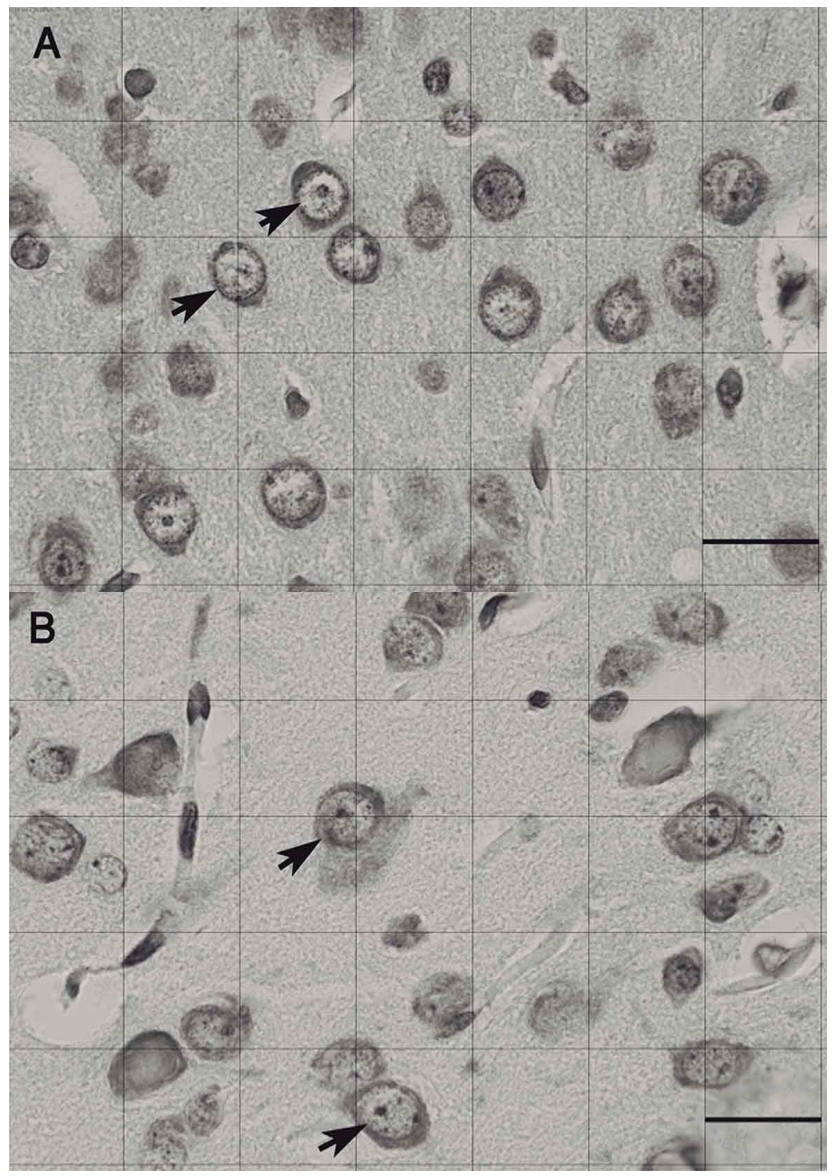

Fig. 1. Histological photograph of brain cortex, primary motor area in Wistar rat offsprings (P32) in control (A) and case (B) groups (1000X magnification, Grid: 20x20 $\mu \mathrm{m}$, Scale bar: $20 \mu \mathrm{m}$, Cresylviolet staining, Arrows showing the pyramidal cells in IPL). 
attached to OLYSIA autobioreport software (Olympus Optical, Co. LTD, Tokyo, Japan). The density of the giant pyramidal neurons was evaluated in $100000 \mu \mathrm{m}^{2}$ area of primary motor cortex in $1000 \mathrm{X}$ magnification (Fig. 1). Also the thickness of the Betz layer was obtained from 200X magnification.

Statistical analysis. Morphometric data are summarized with the Mean \pm SE. the results were analyzed with the Student's " $t$ " test using SPSS 16 software. $\mathrm{P}<0.05$ was considered significant.

\section{RESULTS}

The morphometric findings are depicted in Table I. The density of the giant pyramidal neurons in $100000 \mu \mathrm{m}^{2}$ area of primary motor cortex in $\mathrm{P} 28$, significantly reduced from $86.85 \pm 2.1$ in controls to $64.14 \pm 4.2$ in gestational diabetics offspring $(\mathrm{p}<0.008)$.

Also, the density of the giant pyramidal neurons in primary motor cortex of treated group significantly reduced from 74.85 \pm 3.0 to $60.42 \pm 4.0$ in P56 and from 65.25 \pm 2.2 to $49.57 \pm 2.5$ in $10000 \mu \mathrm{m}^{2}$ area in P84 (p<0.01).

The area and diameter of the giant pyramidal neurons, in primary motor cortex in P28, P56 and P56 in the treated groups were significantly increased in comparison with the controls (Table I).

The mean thickness $(\mu \mathrm{m})$ of the Betz layer in the primary motor cortex in P28, P56 and P84, significantly increased in diabetics $(944.63 \pm 26.0,917.62 \pm 43.4$,
$1071.31 \pm 25.5)$ in comparison with the controls $(755.5 \pm 29.0$, $810.88 \pm 20.2,972.46 \pm 26.1)(\mathrm{p}<0.05)$.

\section{DISCUSSION}

The present study demonstrated that gestational diabetes produces a significant reduction in the giant pyramidal neurons density of brain cortex of rat offspring in the postnatal days of 24, 56 and 84 .

Previous animal model studies have shown that dams with type 1 and 2 diabetes mellitus born offspring with low neuronal density in hippocampus (Beauquis et al., 2006; Li et al., 2002), catecholaminergic systems of hypothalamus (Plagemann et al., 1998), granule layer of dentate gyrus (Ahmadpour \& Haghir) and cerebrum (Khaksar et al.).

Also, several studies have reported reduction of neuronal density in dentate gyrus of animals with type 1 and 2 diabetes mellitus (Hwang et al., 2008; Kim et al., 2003; Li et al., 2002).

Hwang study showed that type II diabetes reduced hippocampal cell differentiation in the subgranular zone of the dentate gyrus in rat model (Hwang et al.).

Furthermore, Khaksar et al. study, showed that neural cell density in gray matter of brain and spinal cord reduces in offspring of diabetic rats. Martinez-Tellez et al. (2005), explained that diabetes mellitus might affect on the dendritic morphology in the limbic structures, prefrontal cortex, occipital cortex, and hippocampus.

Table I. The quantitative characteristics of the Betz cells of cerebrum and internal pyramidal layer thickness in postnatal day 28, 56 and 28 of gestational diabetes mellitus (GD) and control mothers in Wistar rat.

\begin{tabular}{|c|c|c|c|c|}
\hline & Characteristics & Control & GD & $P$ - value \\
\hline \multirow[t]{4}{*}{$\mathbf{P 2 8}$} & Betz density (Betz Number $/ 100000 \mathrm{~m}^{2}$ area of IPL) & $86.85 \pm 2.1$ & $64.14 \pm 4.2$ & 0.008 \\
\hline & Area of Betzs $\left(\mathrm{m}^{2}\right)$ & $109.34 \pm 6.6$ & $153.56 \pm 7.2$ & 0.03 \\
\hline & Diameter of Betzs ( $\mathrm{m})$ & $12.30 \pm 0.2$ & $13.24 \pm 0.3$ & 0.001 \\
\hline & Thickness of IPL (_m) & $755.5 \pm 29.0$ & $944.63 \pm 26.0$ & 0.005 \\
\hline \multirow[t]{4}{*}{ P56 } & Betz density (Betz Number $/ 10000 \_\mathrm{m}^{2}$ area of IPL) & $74.85 \pm 3.0$ & $60.42 \pm 4.0$ & 0.01 \\
\hline & Area of Betzs $\left(\mathrm{m}^{2}\right)$ & $105.95 \pm 3.3$ & $172.39 \pm 6.8$ & 0.001 \\
\hline & Diameter of Betzs ( $\mathrm{m})$ & $10.06 \pm 0.2$ & $12.5 \pm 0.4$ & 0.001 \\
\hline & Thickness of IPL ( $\mathrm{m})$ & $810.88 \pm 20.2$ & $917.62 \pm 43.4$ & 0.04 \\
\hline \multirow[t]{4}{*}{ P84 } & Betz density (Betz Number $/ 10000 \_\mathrm{m}^{2}$ area of IPL) & $65.25 \pm 2.2$ & $49.57 \pm 2.5$ & 0.001 \\
\hline & Area of Betzs $\left(\mathrm{m}^{2}\right)$ & $147.29 \pm 4.4$ & $181.38 \pm 10.1$ & 0.001 \\
\hline & Diameter of Betzs ( m) & $12.63 \pm 0.2$ & $13.54 \pm 0.2$ & 0.02 \\
\hline & Thickness of IPL ( $\mathrm{m}$ ) & $972.46 \pm 26.1$ & $1071.31 \pm 25.5$ & 0.02 \\
\hline
\end{tabular}


Also, our previous studies indicated that gestational diabetes reduces the neuronal density of CA1 and CA3 of hippocampus, anterior horn of spinal cord and cerebellum cortex in rat offspring (Golalipour et al., 2012, 2014; Najafdari et al.; Razi et al.).

In spite of several studies regarding the effects of diabetes I and II and gestational diabetes on CNS, there is no investigation about the effect of gestational diabetes on brain cortex neurons in offspring.

Our animal model study demonstrated that gestational diabetes similar to type I and II diabetes mellitus, has a neurotoxic effect on offspring brain cortex neurons.

Regardless of diabetes mellitus type, it is associated with hyperglycemia. Several possible mechanisms are explained about cerebral alterations including neuronal loss due to hyperglycemia.

One possible mechanism in cause of program cell deaths in diabetes mellitus (Allen et al., 2005; Arroba et al., 2003, 2005, 2007; Klein et al., 2004; Lechuga-Sancho et al., 2006a, 2006b; Nishikawa \& Araki, 2007) can be due to decrease of insulin or insulin-like growth factor signaling (Ishii, 1995) or an increase in cytokines such as TNFa (Chen \& Goeddel, 2002).

Moreover, insulin-like growth factor has a neuroprotective anti-apoptotic effect (Rizzo et al., 1991) and down regulation of expression of insulin-like growth factor and its receptor in diabetes might also be expected to lead to neuronal loss (Li et al., 2002; Russell \& Feldman, 1999).

Diabetes mellitus is considered a chronic endogenous stressor which is related with increased oxidative stress in central nervous system (Ahmadpour et al., 2010; Grillo et al., 2005).

CNS complications of diabetes mellitus could be mediated through excessive free radicals generation (Ahmadpour \& Haghir; Okouchi et al., 2005; Ziegler et al., 2004). Free radicals by oxidizing proteins, damaging DNA, and inducing the lipoperoxidation of cellular membranes contribute to increased neuronal death (Hawkins \& Davies, 2001).

Indeed, several studies have shown that offspring of diabetic mothers have lower arachidonic acid (AA:20:4n-6) and docosahexaenoic acid (DHA:22:6n-3) in cord blood (Min et al., 2005; Wijendran et al., 2000). Arachidonic acid metabolite and prostaglandin E2 play an important role in neurogenesis (Uchida et al., 2002).
Zhao et al. (2009) have reported that maternal arachidonic acid supplementation improves neurodevelopment in young adult offspring from rat dams with and without diabetes. Other factors in active response in hyperglycemia, is down regulation of nitric oxide synthase (NOS) mRNA and protein concentrations are within hippocampal CA1 and CA3 neurons (Reagan \& McEwen, 2002).

This down regulation of NOS mRNA may provide a partial explanation for the impaired long-term potentiation that is seen in the diabetic hippocampus, because induction and maintenance of potentiation are dependent on NOS activity and experimental inhibition of NOS decreases long-term potentiation and impairs cognitive learning and memory (Hölscher, 1997).

Diabetes may enhance the development of stroke via increased cortical apoptotic activity but this was not additive in the hippocampus following ischemic injury (Li et al., 2004).

Also, the thickness of internal pyramidal layer in primary motor cortex may be due to increasing microglia and other glial cells because of inflammation reaction and increased vascular permeability in brain vessels and nervous cell death and astroglial reaction following realize cytokine and interleukin 1 (Beauquis et al., 2008).

This study showed that uncontrolled gestational diabetes induces adverse effects on Betz neurons in offspring brain cortex, which remained persistent during postnatal period. Further studies are required for exploring the exact mechanism of CNS complications of gestational diabetes mellitus.

ACKNOWLEDGMENT. We thank the Deputy research of Golestan University of medical sciences for financial support (Grant number: 35-1357).

GHAFARI, S.; GOLALIPOUR, E. \& GOLALIPOUR, M. J. Alteraciones de las neuronas piramidales gigantes de la corteza cerebral en crías de ratas nacidas de hembras con diabetes gestacional: un estudio morfométrico. Int. J. Morphol., 33(3):1120-1125, 2015.

RESUMEN: Pocos estudios han informado de los efectos adversos de la diabetes gestacional sobre las células del hipocampo y médula espinal. Este estudio, se realizó para determinar el efecto de la diabetes gestacional sobre las neuronas piramidales gigantes ubicadas en la quinta capas de la sustancia gris en la corteza motora primaria y el espesor de la capa piramidal interna en la corteza cerebral en crías de ratas. En el día 1 de la gestación, 10 ratas Wistar se asignaron aleatoriamente en dos grupos: control y diabéticos. Cinco animales del grupo diabético, fueron inyectados con $40 \mathrm{mg} / \mathrm{kg}$ de peso corporal de estreptozotocina (por vía intraperitoneal), y los de el grupo control, con solución salina. Aleatoriamente, se selecciona- 
ron seis crías de cada hembra de ambos grupos los días 28, 56 y 84. Las crías fueron sacrificadas, se tomaron secciones coronales de la corteza cerebral derecha y se tiñeron con violeta de cresilo. Se evaluó la densidad de las neuronas piramidales gigantes en la corteza cerebral y el espesor de la capa piramidal interna de la corteza cerebral. En los días 28, 56, 84 la densidad de las neuronas piramidales gigantes en corteza cerebral se redujo significativamente al comparar los controles $(107,6 \pm 6,2,131,6 \pm 4,6$ y $143,5 \pm 4,0$ respectivamente) con los casos $(84,96 \pm 2,1,109,8 \pm 7,3$ y $121,05 \pm 5,6$ respectivamente) $(\mathrm{p}<0,05)$. El espesor de la capa piramidal interna de la corteza cerebral en los días 28,84 y 56 fue significativamente mayor en el grupo diabético gestacional en comparación con el grupo control ( $\mathrm{p}<0,05)$. Este estudio muestra que la diabetes gestacional no controlada reduce la densidad de neuronas piramidales gigantesy el espesor interno de la capa piramidal en la corteza cerebral de las crías de rata.

PALABRAS CLAVE: Diabetes gestacional; Neuronas; Neuronas piramidales gigantes; Corteza cerebral; Crías de Rata.

\section{REFERENCES}

Ahmadpour, S. H. \& Haghir, H. Diabetes mellitus type 1 induces dark neuron formation in the dentate gyrus: a study by Gallyas' method and transmission electron microscopy. Rom. J. Morphol. Embryol., 52(2):5759, 2011.

Ahmadpour, S. H.; Sadeghi, Y. \& Haghir, H. Streptozotocin induced hyperglycemia produces dark neuron in $\mathrm{CA} 3$ region of hippocampus in rats. Asian J. Med. Sci., 2(1):11-5, 2010.

Allen, D. A.; Yaqoob, M. M. \& Harwood, S. M. Mechanisms of high glucoseinduced apoptosis and its relationship to diabetic complications. J. Nutr. Biochem., 16(12):705-13, 2005.

Arroba, A. I.; Frago, L. M.; Pañeda, C.; Argente, J. \& Chowen, J. A. The number of lactotrophs is reduced in the anterior pituitary of streptozotocininduced diabetic rats. Diabetologia, 46(5):634-8, 2003.

Arroba, A. I.; Frago, L. M.; Argente, J. \& Chowen, J. A. Activation of caspase 8 in the pituitaries of streptozotocin-induced diabetic rats: implication in increased apoptosis of lactotrophs. Endocrinology, 146(10):4417-24, 2005.

Arroba, A. I.; Lechuga-Sancho, A. M.; Frago, L. M.; Argente, J. \& Chowen, J. A. Cell-specific expression of $\mathrm{X}$-linked inhibitor of apoptosis in the anterior pituitary of streptozotocin-induced diabetic rats. J. Endocrinol., 192(1):215-27, 2007.

Beauquis, J.; Roig, P.; Homo-Delarche, F.; De Nicola, A. \& Saravia, F. Reduced hippocampal neurogenesis and number of hilar neurones in streptozotocininduced diabetic mice: reversion by antidepressant treatment. Eur. J. Neurosci., 23(6):1539-46, 2006

Beauquis, J.; Saravia, F.; Coulaud, J.; Roig, P.; Dardenne, M.; Homo-Delarche, F. \& De Nicola, A. Prominently decreased hippocampal neurogenesis in a spontaneous model of type 1 diabetes, the nonobese diabetic mouse. Exp. Neurol., 210(2):359-67, 2008.

Biessels, G. J.; van der Heide, L. P. V.; Kamal, A.; Bleys, R. L. \& Gispen, W. H. Ageing and diabetes: implications for brain function. Eur. J. Pharmacol., 441(1-2):1-14, 2002.
Chen, G. \& Goeddel, D. V. TNF-R1 signaling: a beautiful pathway. Science, 296(5573):1634-5, 2002.

DeBoer, T.; Wewerka, S.; Bauer, P. J.; Georgieff, M. K. \& Nelson, C. A. Explicit memory performance in infants of diabetic mothers at 1 year of age. Dev. Med. Child. Neurol., 47(8):525-31, 2005.

Fahrenkrog, S.; Harder, T.; Stolaczyk, E.; Melchior, K.; Franke, K.; Dudenhausen, J. W. \& Plagemann, A. Cross-fostering to diabetic rat dams affects early development of mediobasal hypothalamic nuclei regulating food intake, body weight, and metabolism. J. Nutr., 134(3):648-54, 2004.

Gardoni, F.; Kamal, A.; Bellone, C.; Biessels, G. J.; Ramakers, G. M.; Cattabeni, F.; Gispent, W. H. \& Di Luca, M. Effects of streptozotocindiabetes on the hippocampal NMDA receptor complex in rats. $J$. Neurochem., 80(3):438-47, 2002.

Gispen, W. H. \& Biessels, G. J. Cognition and synaptic plasticity in diabetes mellitus. Trends Neurosci., 23(11):542-9, 2000.

Golalipour, M. J.; Kafshgiri, S. K. \& Ghafari, S. Gestational diabetes induced neuronal loss in CA1 and CA3 subfields of rat hippocampus in early postnatal life. Folia Morphol. (Warsz.), 71(2):71-7, 2012.

Golalipour, M. J.; Ghafari, S. \& Moharerri, A. R. Gestational diabetes reduces motor neurons of spinal cord in 4, 8 and 12 weeks rat offspring. $J$. Gorgan Univ. Med. Sci., 16(1):39-45, 2014.

Grillo, C. A.; Piroli, G. G.; Wood, G. E.; Reznikov, L. R.; McEwen, B. S. \& Reagan, L. P. Immunocytochemical analysis of synaptic proteins provides new insights into diabetes-mediated plasticity in the rat hippocampus. Neuroscience, 136(2):477-86, 2005.

Hawkins, C. L. \& Davies, M. J. Generation and propagation of radical reactions on proteins. Biochim. Biophys. Acta, 1504(2-3):196-219, 2001.

Hölscher, C. Nitric oxide, the enigmatic neuronal messenger: its role in synaptic plasticity. Trends Neurosci., 20(7):298-303, 1997.

Hwang, I. K.; Yi, S. S.; Kim, Y. N.; Kim, I. Y.; Lee, I. S.; Yoon, Y. S. \& Seong, J. K. Reduced hippocampal cell differentiation in the subgranular zone of the dentate gyrus in a rat model of type II diabetes. Neurochem. Res., 33(3):394-400, 2008.

Ishii, D. N. Implication of insulin-like growth factors in the pathogenesis of diabetic neuropathy. Brain Res. Brain Res. Rev., 20(1):47-67, 1995.

Jackson-Guilford, J.; Leander, J. D. \& Nisenbaum, L. K. The effect of streptozotocin-induced diabetes on cell proliferation in the rat dentate gyrus. Neurosci. Lett., 293(2):91-4, 2000.

Khaksar, Z.; Jelodar, G. \& Hematian, H. Effect of maternal diabetes on cerebellum histomorphometry in neonatal rats. J. Shaheed Sadoughi Univ. Med. Sci. Health Serv., 18(1):56-63, 2010.

Kim, H.; Jang, M. H.; Shin, M. C.; Chang, H. K.; Lee, T. H.; Lim, B. V.; Jung, C. Y.; Lee, C. Y.; Kim, E. H. \& Kim, C. J. Folium mori increases cell proliferation and neuropeptide $\mathrm{Y}$ expression in dentate gyrus of streptozotocin-induced diabetic rats. Biol. Pharm. Bull., 26(4):434-7, 2003.

Klein, J. P.; Hains, B. C.; Craner, M. J.; Black, J. A. \& Waxman, S. G. Apoptosis of vasopressinergic hypothalamic neurons in chronic diabetes mellitus. Neurobiol. Dis., 15(2):221-8, 2004. 
Lebed, Y. V.; Orlovsky, M. A.; Nikonenko, A. G.; Ushakova, G. A. \& Skibo, G. G. Early reaction of astroglial cells in rat hippocampus to streptozotocininduced diabetes. Neurosci. Lett., 444(2):181-5, 2008.

Lechuga-Sancho, A. M.; Arroba, A. I.; Frago, L. M.; García-Cáceres, C.; de Célix, A. D.; Argente, J. \& Chowen, J. A. Reduction in the number of astrocytes and their projections is associated with increased synaptic protein density in the hypothalamus of poorly controlled diabetic rats. Endocrinology, 147(11):5314-24, 2006a.

Lechuga-Sancho, A. M.; Arroba, A. I.; Frago, L. M.; Pañeda, C.; García-Cáceres, C.; Delgado Rubín de Célix, A.; Argente, J. \& Chowen, J. A. Activation of the intrinsic cell death pathway, increased apoptosis and modulation of astrocytes in the cerebellum of diabetic rats. Neurobiol. Dis., 23(2):290-9, 2006 b.

Li, Z. G.; Britton, M.; Sima, A. A. \& Dunbar, J. C. Diabetes enhances apoptosis induced by cerebral ischemia. Life Sci., 76(3):249-62, 2004.

Li, Z. G.; Zhang, W.; Grunberger, G. \& Sima, A. A. Hippocampal neuronal apoptosis in type 1 diabetes. Brain Res., 946(2):221-31, 2002.

Martínez-Tellez, R.; Gómez-Villalobos, Mde. J. \& Flores, G. Alteration in dendritic morphology of cortical neurons in rats with diabetes mellitus induced by streptozotocin. Brain Res., 1048(1-2):108-15, 2005.

McCall, A. L. The impact of diabetes on the CNS. Diabetes, 41(5):557-70, 1992.

Min, Y.; Lowy, C.; Ghebremeskel, K.; Thomas, B.; Offley-Shore, B. \& Crawford, M. Unfavorable effect of type 1 and type 2 diabetes on maternal and fetal essential fatty acid status: a potential marker of fetal insulin resistance. Am. J. Clin. Nutr., 82(6):1162-8, 2005.

Najafdari, S.; Rezaei, N.; Shafaroodi, M. M.; Ghafari, S. \& Golalipour , M. J. Ganglionic cells apoptosis in retinal layer of rat offspring due to gestational diabetes. Int. J. Morphol., 32(4):1131-5, 2014.

Nelson, C. A.; Wewerka, S.; Thomas, K. M.; Tribby-Walbridge, S.; deRegnier, R. \& Georgieff, M. Neurocognitive sequelae of infants of diabetic mothers. Behav. Neurosci., 114(5):950-6, 2000.

Nishikawa, T. \& Araki, E. Impact of mitochondrial ROS production in the pathogenesis of diabetes mellitus and its complications. Antioxid. Redox Signal., 9(3):343-53, 2007.

Okouchi, M.; Okayama, N. \& Aw, T. Y. Differential susceptibility of naive and differentiated PC-12 cells to methylglyoxal-induced apoptosis: influence of cellular redox. Curr. Neurovasc. Res., 2(1):13-22, 2005.

Ornoy, A. Growth and neurodevelopmental outcome of children born to mothers with pregestational and gestational diabetes. Pediatr. Endocrinol. Rev., $3(2): 104-13,2005$.

Paxinos, G. \& Watson, C. The Rat Brain in Stereotaxic Coordinates. 6th ed. New York Academic Press, 1998. pp.451.

Persaud, O. D. D. Maternal diabetes and the consequences for her offspring. $J$. Dev. Disabil., 13(1):101-33, 2007.

Piotrowski, P.; Wierzbicka, K. \& Smia?ek, M. Neuronal death in the rat hippocampus in experimental diabetes and cerebral ischaemia treated with antioxidants. Folia Neuropathol., 39(3):147-54, 2001.

Plagemann, A.; Harder, T.; Lindner, R.; Melchior, K.; Rake, A.; Rittel, F.; Rohde, W. \& Dörner, G. Alterations of hypothalamic catecholamines in the newborn offspring of gestational diabetic mother rats. Brain Res. Dev. Brain Res., 109(2):201-9, 1998
Razi, E. M.; Ghafari, S.; Hojati, V. \& Golalipour, M. J. Effect of Gestational diabetes on neuronal cells in rat cerebellum in early postnatal life. Int. J. Morphol., 32(2):420-5, 2014.

Reagan, L. P. \& McEwen, B. S. Diabetes, but not stress, reduces neuronal nitric oxide synthase expression in rat hippocampus: implications for hippocampal synaptic plasticity. Neuroreport, 13(14):1801-4, 2002.

Rizzo, T.; Metzger, B. E.; Burns, W. J. \& Burns, K. Correlations between antepartum maternal metabolism and child intelligence. N. Engl. J. Med., 325(13):911-6, 1991

Russell, J. W. \& Feldman, E. L. Insulin-like growth factor-I prevents apoptosis in sympathetic neurons exposed to high glucose. Horm. Metab. Res., 31(23):90-6, 1999.

Saravia, F. E.; Revsin, Y.; Gonzalez Deniselle, M. C.; Gonzalez, S. L.; Roig, P.; Lima, A.; Homo-Delarche, F. \& De Nicola, A. F. Increased astrocyte reactivity in the hippocampus of murine models of type 1 diabetes: the nonobese diabetic (NOD) and streptozotocin-treated mice. Brain Res., 957(2):345-53, 2002

Schoenle, E. J.; Schoenle, D.; Molinari, L. \& Largo, R. H. Impaired intellectual development in children with Type I diabetes: association with $\mathrm{HbA}(1 \mathrm{c})$, age at diagnosis and sex. Diabetologia, 45(1):108-14, 2002.

Siddappa, A. M.; Georgieff, M. K.; Wewerka, S.; Worwa, C.; Nelson, C. A. \& Deregnier, R. A. Iron deficiency alters auditory recognition memory in newborn infants of diabetic mothers. Pediatr. Res., 55(6):1034-41, 2004.

Uchida, K.; Kumihashi, K.; Kurosawa, S.; Kobayashi, T.; Itoi, K. \& Machida, T. Stimulatory effects of prostaglandin E2 on neurogenesis in the dentate gyrus of the adult rat. Zoolog. Sci., 19(11):1211-6, 2002.

Wijendran, V.; Bendel, R. B.; Couch, S. C.; Philipson, E. H.; Cheruku, S. \& Lammi-Keefe, C. J. Fetal erythrocyte phospholipid polyunsaturated fatty acids are altered in pregnancy complicated with gestational diabetes mellitus. Lipids, 35(8):927-31, 2000.

Zhao, J.; Del Bigio, M. R. \& Weiler, H. A. Maternal arachidonic acid supplementation improves neurodevelopment of offspring from healthy and diabetic rats. Prostaglandins Leukot. Essent. Fatty Acids, 81(5-6):34956,2009 .

Ziegler, D.; Sohr, C. G. \& Nourooz-Zadeh, J. Oxidative stress and antioxidant defense in relation to the severity of diabetic polyneuropathy and cardiovascular autonomic neuropathy. Diabetes Care, 27(9):2178-83, 2004.

\section{Correspondence to: \\ Mohammad Jafar Golalipour \\ Gorgan Congenital Malformations Research Center \\ Department of Anatomical Sciences \\ Golestan University of Medical Sciences \\ Gorgan \\ IRAN}

P.O. Box: 49175-1141

Phone: + 98(17)34425165 Received: 04-03-2015 Accepted: 13-07-2015

Email: mjgolalipour@yahoo.com 